\title{
Asymmetrical corporate responses to economic information: Applying the firm size effect
}

\author{
Jae-woong Yoo ${ }^{1,{ }^{*}}$, Min-Kyu Lee ${ }^{2}$, Wan Soo Lee ${ }^{3}$ \\ ${ }^{1,3}$ Dongseo University, Busan South Korea \\ ${ }^{2}$ Chung-Ang University, Seoul, South Korea
}

\section{Keywords:}

Economic communication

Economic conditions

Business sentiments

Media coverage

Perception of the economy

Firm size

Received: 31 December 2015

Accepted: 12 January 2016

Published: 22 February 2016

\begin{abstract}
This research utilized longitudinal economic data to analyze differences by firm size in how business sentiments are affected by economic news and economic conditions. A regression was also conducted for the relationship between firm-specific BSI (Business Survey Index) values and rate of employees and business activities. Results showed no statistically significant effect from economic news tone on business sentiment for large firm sizes as opposed to individuals. At the same time, the economic situation was found to have an effect on business sentiment regardless of firm size. Anticipated future economic conditions exhibited an effect on business sentiment regardless of firm size, but current economic conditions had an effect on business sentiment only for small firms. Business sentiment had an effect on business activities according to GDP rate, regardless of firm size. Theoretical and managerial implications as well as directions for future research are discussed.
\end{abstract}

(C) 2016 The Author(s). Published by TAF Publishing.

\section{INTRODUCTION}

Many researchers have suggested that a nation's economic situation and media coverage of it affect individuals' perceptions of the economy. It has also been hypothesized that economic beliefs among individuals influence actual economic activity. Economic communication research to date has been characterized by a simple dichotomy at the individual level, with questions demanding simplistic responses such as "yes" and "no" or "strong" and "weak" (Scheufele \& Tewksbury, 2007). The effects of economic communication are broadly accepted among media researchers, but it cannot be concluded simply that the effects of economic communication at the individual level

\footnotetext{
*Corresponding author: Jae-woongYoo

E-mail: yoojw777@hanmail.net
}

are equivalent at the organizational level, as organizations have stronger resources than individuals in terms of collecting, processing, and interpreting information.

Organizations of different sizes respond differently to the external environment (Banz, 1981). Business size is an important factor to consider when attempting to gauge the formation of business sentiments and firm performance as well as media effects on firms. Considerable evidence exists that a firm's size is related to its productivity, survival, and profitability (Beck, Demirguc-Kunt \& Maksimovic, 2005) as well as its collective psychology (Ji, 2011). Economic cycles also have profound effects on firms: while large firms dominate news headlines when an economy is in recession, many small and medium-sized enterprises are more vulnerable to news reporting. Furthermore, small firms perform significantly worse than large firms when economic conditions are poor (Kim \& 
Burnie, 2002). Compared to large firms, small firms are more strongly influenced by media coverage and the nation's economic health. Firms of different sizes respond differently to economic conditions and news reports (e.g. Banz, 1981; Bovi, 2009; Daft \& Lengel, 1986; Kim \& Burnie, 2002; Mutz, 1998; Reinganum, 1981; Soroka, 2006). Few holistic studies have been conducted on economic communication effects at the organization level by size. This study aims to comprehensively analyze how economic communication effects differ according to the information processing model at the organization level and the theory of firm size effects (Banz, 1981; Reinganum, 1981).

The goal of this study is to examine whether, and to what extent, South Korean economic conditions and economic news coverage affect business sentiments, as differentiated by firm size. It focuses on (a) whether economic news have differential influences on business sentiments by firm size; (b) whether economic news exert a negative influence on corporate business sentiments when economic conditions are poor; (c) whether economic conditions affect managers' sentiments at firms of different sizes; and (d) whether economic prospects have differential effects on production facilities, and/or employment by firm size. This study has the aim of broadening the theoretical scope of economic communication research by gaining an understanding of the differences between individuals and business organizations, as well as measuring the complex relationships of firm size. In practical terms, it attempts to examine interactions among economic news, economic conditions, business sentiments, and business activities for their implications in understanding and applying media variables to formulate and execute real economic policy.

\section{LITERATURE REVIEW}

Business sentiments and organizational methods of media information processing that individuals and firms employ use differential methods to acquire information. While it is impossible for an individual to have a complete set of mental skills, habits, and reflexes for comprehensive knowledge and information processing (Choo, 1996), an organization is capable of overcoming these unavoidable limitations on the individual. As Schneider once concluded, an individual is limited in his or her ability to understand and interpret media coverage, but the internal system of a firm has the ability to collect, understand, compare, and interpret related media coverage (Schneider, 1997). (Boomgaarden et al., 2011) discussed the disconnect between personal and national economic evaluations with regard to mass-mediated economic information. Individuals in an organization send and receive data to obtain suitable information. However, organizational information processing consists of more than what occurs among individuals (Daft \& Weick, 1984). One distinguishing feature of organizational information processing is the need to cope with diversity, which is not typical of an isolated individual (Daft \& Lengel, 1986). Generally, organizations search for and evaluate information to make important decisions (Choo, 1996). Information processing at the organizational level is distinct from the informational activities of individuals in its need to bridge disputes and diversity of opinions (Daft \& Lengel, 1986). In contrast, firms possess the resources to understand a nation's economic situation through their own systems of information processing, interpretation, and evaluation (Sims, 2003; Turner \& Makhija, 2012).

While business organizations tend to evaluate situations more cautiously, systematically, and holistically to their industries than reporters, news provide important information for the investment and employment decisions of a firm (Choo, 1996). Therefore, media coverage is but one of many factors that firms consider when evaluating economic conditions; others include financial status, sales, stocks, and labor productivity. This leads to a decreased reliance on media for organizations compared to individuals when attempting to understand economic conditions.

Research shows that corporate and individual economic actors tend to interpret economic information differently under different economic conditions. Some studies have found that people pay much more attention to economic reports from mass media when economic conditions are poor than when they are good (Alwathainani, 2010; Headrick \& Lanoue, 1991; Wu et al., 2002). Goidel and Langley (1985) also found that the public is more vulnerable during an economic slump, even after the effects of the state of the economy are controlled. However, some studies have shown that perceptions of the economy can be predicted from economic indicators rather than media coverage of a recession. For example, (Wu, McCracken \& Saito, 2004) found that public concern was determined more by reality indicators than by news coverage, indicating the limited effect of media coverage.

Economic conditions, business sentiments and firm size with respect to the relationship between economic situations and business sentiments, (Linden, 1982) noted that people are indeed sensitive to their personal day-to- 
day economic activities (Blood \& Phillips, 1995). The effects of economic conditions on business sentiments are reflected in non-mediated experiences. People's sentiments about the economy are not influenced by news coverage, but rather by economic conditions.

Because economic conditions represent a prominent issue accessible to people's direct experience (Zucker, 1978) it appears that people base their perceptions of the health of the nation's economy on their experiences (Haller \& Norpoth, 1997; Linden, 1982). If people experience financial setbacks in their own lives, they perceive actual economic circumstances in a negative light. Conversely, if life is good, they view economic circumstances positively. Objective economic circumstances have a greater influence on the subjective business perceptions of consumers than any other factor (Behr \& Iyengar, 1985; De Boef \& Kellstedt, 2004). Haller \& Norpoth (1997) did not find any differences in the understanding of economic situations among people exposed to economic news and those not exposed to economic news; they empirically determined a similarity between indices reflecting the economic reality and the aggregate opinion of "no-news" respondents.

Many findings to date have suggested that people's judgments on the economy are influenced by business conditions (Blood \& Phillips, 1995; Eshbaugh-Soha \& Peake, 2005). This assertion applies especially strongly to the national economy, rather than merely to the individual experience (Mutz, 1998). The mass media act as an important information source, playing a pivotal role in shaping perceptions of aggregate social realities and building a picture out of individual experiences (Mutz, 1998). However, psychological perceptions of collective economic conditions rely on direct individual experiences and interests rather than on media. Thus, a corporation's perception of inner circumstances is not a collective one based on the national economy, but rather an individual one based on corporate management. Economic conditions are deemed to have a greater influence on the perception of business realities than the news (Behr \& Iyengar, 1985; De Boef \& Kellstedt, 2004). As people experience economic issues in everyday life, they do not rely entirely on news reports (Blood \& Phillips, 1995; Linden, 1982), but rather confirm those reports against their own everyday experiences (Haller \& Norpoth, 1997).

At the same time, it has been claimed that corporate psychological responses to the economic reality vary by firm size. Shocks are invariably distributed unevenly by industrial scale, sector, and sometimes region. Firms of different sizes respond differently to policies, public conflicts, and economic conditions. Economists have begun to consider firm size as an important variable in reviewing how firms respond to outer environments (Beck et al., 2005). Firms have heterogeneous characteristics, inter alia in terms of history, size, ownership, sales orientation, access to technology, and financial arrangement (Narjoko \& Hill, 2007).

Companies rely chiefly on economic conditions and economic information such as that found in news reports. However, responses to economic situations or news reports vary by firm size. A recession at the national level may have differential effects on companies of different sizes (Avraham, 1993). Small firms are more likely to respond readily to market information than larger ones (Kim \& Burnie, 2002). Thus, small firms suffer from an acute lack of public information or asymmetric information (Elfakhani \& Zaher, 1998). Larger firms, on the other hand, might be expected to be more competitive, owing to economies of scale, market power, and greater financial resources. While large firms have the resources and strategic management capabilities to conceive and develop new future core competencies, small firms are rarely equipped for such a fundamental long-term planning process (Shrader, Mulford \& Blackburn, 1989). Many studies have proposed that large firms are less affected or hurt by the external environment than smaller ones (He, Mian \& Sankaraguruswamy, 2007; Reinganum, 1981). Accordingly, this study adopts the following research questions:

RQ1: What differences are observed in the effects of economic news on business sentiments by firm size?

RQ2: What differences are observed in the effects of economic conditions on business sentiments by firm size? Business sentiments, business activities, and firm size In terms of the relationship between business sentiments and business activities (Katona, 1964) argued that changes in consumer sentiment can serve as a leading indicator for future economic activity (Blood \& Phillips, 1995; Curtin, 1982). He noted that the economy may improve or deteriorate depending on people's economic perception, a phenomenon that he referred to as the "psychological aspect of the economy." Many studies have supported Katona's (1964) finding that change in consumer sentiment is an important antecedent variable for future economic activities (Fuhrer, 1988; Matsusaka \& Sbornone, 1992; Wu et al., 2002; Wu et al., 2004). Psychological 
responses exert great influence on the real economy (Blood \& Phillips, 1995; Lewis, 2008; Roland-Levy \& Kirchler, 2009). In this respect, a self-fulfilling prophecy appears to apply, such that the actual state of the economy is decided by consumer psychology. Ranyard et al. (2008) proposed a psychological framework based on the recognition or expectation of changes in commodity prices, which is perceived to guide personal economic activities such as consumption or saving.

Personal economic activities are influenced by perceptions of current commodity prices or expectations regarding future prices. (Sill, 2009) discovered a causal relationship between consumer expectations and the actual amount of consumable sales. This finding showed that the sales volume of consumer goods did not affect consumer sentiments, whereas consumer sentiments did affect sales. Other studies have found positive relationships between consumer sentiments and consuming activities (Shirvani \& Wilbratte, 2008; Uhl, 2011). However, (Blood \& Phillips, 1995) found no relationship between consumer sentiments and consumption activities with respect to U.S. economic issues. Productivity may vary by firm size, and is influenced not only by staff, facility, resource, and economic strategy factors but also by factors related to scale. While business psychology appears to affect business activities in general terms, this relationship has not been empirically examined when firm size is simultaneously considered (Kim \& Burnie, 2002). Based on the literature described above, the following research question is proposed:

RQ3: What are the effects of business sentiments on business activities, and what differences exist by firm size?

\section{METHOD}

\section{Research Design}

This study applied regression analysis to investigate the causal relationships among four critical variables in business communication: economic news, business sentiments, economic conditions, and business activities. More specifically, it focused on examining whether economic news reports or economic conditions affect business sentiments and what differences exist by firm size, by processing the period of business recession with dummy variables. Thus, a regression was performed for the relationships between firm-specific BSI values and rate of employees and business activities. To establish a more complete picture of the relationships, this process was performed for two separate periods with altered variables.
Differences by firm size in the effects of economic news on business sentiments were examined for the period from February 2003 to August 2007 using data released by the South Korean government. Effects of economic conditions on business activities were examined for the period from the first quarter of 1999 to the fourth quarter of 2007. The difference in the dates of data analyzed owes to the fact that the South Korean government first began releasing Business Survey Index values for business sentiments in 2003. The decision to use post-1999 data on economic conditions and business activities was intended to boost the reliability of predictions by excluding data for the Asian financial crisis, during which time the national economic structure was shaped by rather extreme circumstances.

\section{Measurement}

\section{Economic News}

The data consisted of 1,119 economic news headlines from Korean television and newspapers for a period of 55 months between February 2003 and August 2007. Headline tone was measured on a Likert-type scale with values of very negative $(-2)$, negative $(-1)$, neutral $(0)$, positive (1), and very positive (2). Specifically, headlines were taken from the economic news of four media entities, consisting of two newspapers (ChosunIlbo \& Dong-A Ilbo) and two television broadcast outlets (the networks KBS and SBS) These four outlets were selected as the most influential agenda-setters in South Korean economic news. Economic news were sampled from the front pages of Chosunllbo and Dong-A Ilbo and the evening news programs of KBS and SBS via the Korea Integrated Newspaper Database System and the homepages of the individual media. The resulting values were aggregated on a monthly basis, with a mean tone of media coverage calculated at -0.66 . Two graduate journalism students participated in coding of the economic coverage, with an inter-coder reliability rating (Cohen's kappa value) of 0.89 .

\section{Business Sentiment}

Data for business sentiment variables were derived from BSI (Business Survey Index) values, which are announced on a monthly basis by the Bank of Korea. The BSI is a business prediction tool used to analyze firm activities, future plans, and firm expectations regarding overall business trends for various items. In calculating the BSI, questionnaires were used to evaluate current economic conditions and prospects for future economic conditions as assessed by 2,929 fixed-panel industrialists working in 
management strategy at small and large firms. BSI data consisted of ratings for 15 items on a three-point scale (bad $=-1$, normal $=0$, and good $=1$ ) using the formula (number of firms giving a positive answer-number of firms giving a negative answer) / total number of firms) $\mathrm{x} 100+100$. Note that a BSI of 100 indicates equal positive and negative answers, while a BSI of more than 100 indicates more positive than negative answers. In all other cases, negative answers outnumber positive ones. For the purposes of statistical analysis, non-stationary series were transformed into stationary ones by seasonal adjustment through the Autoregressive Integrated Moving Average model for time series analysis. Non-sampling error was eliminated by focusing on the economic conditions of individual firms rather than national economic conditions.

\section{Economic Conditions}

This study used the leading indices of business indicators and the coincident indices of business indicators, which are announced by Statistics Korea every month. These indices are composite indices of business indicators. For the leading indices (business indicators), year-by-year rates were used to control for external factors that might affect changes in seasons or working days and thereby affect the economic indices. Note that the leading composite index is created by processing various indices, such as the rates at which jobs are sought and offered, stock price indices, and construction and machinery order indices. The year-by-year rates are used to predict business activity in the near future. These rates were used as indices because statistical values require stationary time series.

\section{Business Activities}

To measure firm business activities, this study used GDP rates, plant and equipment investment rates, and the employment rate. This information is reported by the Bank of Korea every quarter as variables in firm business activity. Note that the GDP increase refers to the figure from the same quarter of the preceding year, while the plant and equipment investment increase refers to the increase from the same quarter of the preceding year and is limited specifically to plant and equipment investment related to firm production. In addition, the employment increase figure refers to the rate relative to the number of employees announced by Statistics Korea for the same quarter of the preceding year.

\section{Firm Size}

This study analyzed how dynamics among these businessrelated variables differed depending on firm size. Firm size categorization was based on the definitions in the Bank of Korea's Enforcement Decree of the Basic Act on Small and Medium Businesses, which states that a large firm has more than 300 employees, while small firms have fewer (see www.bok.or.kr).

\section{Analysis Method}

On the assumption that BSI remains constant regardless of corporation size, three variables were examined via regression analysis: the economy, media reporting, and business sentiment. A separate regression analysis was conducted to examine the differing influence of business conditions on BSIs by corporation size. The focus of this examination was on whether news reports affected business sentiments differentially by corporation size, as calculated by processing the period of business recession with dummy variables. Finally, a regression was concluded for the relationships between firm-specific BSIs and rate of employees and business activities.

\section{RESULTS}

After non-stationary data were transformed into stationary data, relationships were calculated for four critical variables in economic communication in South Korea: the state of the economy, economic news, firm manager sentiments, and corporation production activities.

\section{RQ1}

Economic news reports were not found to affect firm business sentiments. All firms, regardless of size, were less likely to be affected by the tone of media coverage. Another point of analysis concerned potential differences in the results of media coverage in times of recession. The results showed that economic news did not affect firm sentiments, regardless of economic conditions. It was therefore concluded that the firms' predictions of economic conditions were not based on media reports.

\section{RQ2}

As Table1 shows, expectations regarding future economic conditions are likely to influence firm sentiments regardless of firm size, when the impact of tone of media coverage on the economy is controlled for. If business was expected to improve in the future, firms predicted that 
economic conditions would also improve; if economic conditions were expected to worsen in the future, firms predicted that economic conditions would deteriorate (small firms: $t=3.20$, large firms: $t=2.51$ ). Anticipated future economic conditions were thus found to affect business sentiments regardless of firm size. It is worth noting, however, that small firms responded with greater sensitivity to future business predictions than large ones did. When psychological attributes of the economy were taken into account, business sentiments were found to be affected by predictions of future economic situations, but psychological sensitivity varied by firm size.

As noted in Table 1, current economic conditions were less likely to influence the business prospects of large firms than small ones when tone of media coverage was controlled for $(t=2.04)$. This suggests that large firms are not greatly affected by current economic conditions in psychological terms, whereas small firms respond more keenly to such conditions. As Table 2 shows, however, tone of media coverage did not affect the business prospects for either small or large firms, nor did it affect prospects when business conditions worsened.

TABLE 1. Regression values for relationship between the economy, media, and BSI (Feb. 2003 to Aug. 2007)

\begin{tabular}{|c|c|c|c|c|c|c|c|c|c|c|c|c|}
\hline \multirow[b]{3}{*}{ Variable } & \multicolumn{4}{|c|}{ Business Conditions BSI } & \multicolumn{4}{|c|}{$\begin{array}{l}\text { Plant and Equipment } \\
\text { Investment BSI }\end{array}$} & \multicolumn{4}{|c|}{ Human Resources BSI } \\
\hline & \multicolumn{2}{|c|}{ Large Firm } & \multicolumn{2}{|c|}{ Small Firm } & \multicolumn{2}{|c|}{ Large Firm } & \multicolumn{2}{|c|}{ Small Firm } & \multicolumn{2}{|c|}{ Large Firm } & \multicolumn{2}{|c|}{ Small Firm } \\
\hline & $\begin{array}{l}\text { Coef } \\
\text { (1) }\end{array}$ & $\mathbf{t}$ & Coef & $\mathbf{T}$ & Coef & $\mathbf{t}$ & Coef & $\mathrm{t}$ & Coef & $\mathbf{t}$ & Coef & $\mathbf{t}$ \\
\hline $\begin{array}{l}\text { Leading composite index } \\
\text { Rate from the same month } \\
\text { of previous year }(-1)\end{array}$ & 2.00 & $\begin{array}{l}2.51 \\
* *\end{array}$ & 2.19 & $\begin{array}{l}3.20 \\
* * *\end{array}$ & 1.61 & $\begin{array}{l}5.48 \\
* * *\end{array}$ & 1.41 & $\begin{array}{l}5.57 \\
* * *\end{array}$ & -0.16 & -0.80 & 0.20 & 0.66 \\
\hline Media coverage tone index & $-\overline{0}$ & $-\overline{0}$ & $-\overline{1}$ & 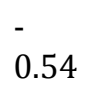 & 1.03 & 0.95 & 0.29 & 0.31 & -0.48 & -0.66 & -0.96 & -0.86 \\
\hline $\begin{array}{l}\text { Media coverage tone index } \\
\text { +Economic recession }\end{array}$ & 1.77 & 0.59 & 0.86 & 0.34 & 0.11 & 0.10 & 1.13 & 1.18 & 0.861 & 152.1 & 51.90 & \\
\hline $\begin{array}{l}\text { Coincident Composite } \\
\text { Index } \\
\text { Cycle variation value(-1) }\end{array}$ & 2.76 & 1.51 & 3.29 & $\begin{array}{l}2.04 \\
* *\end{array}$ & -0.14 & -0.16 & -0.26 & -0.33 & -0.49 & $\overline{-} 1.15$ & $\overline{-} 1.22$ & $\begin{array}{l}- \\
1.97 \\
*\end{array}$ \\
\hline Media coverage tone index & $\overline{-}-15$ & 0.05 & $-\overline{-}$ & $\overline{-}-24$ & 0.990 & & 0.17 & & -0.58 & $\overline{0}-$ & $\overline{-}-1.23$ & - \\
\hline $\begin{array}{l}\text { Media coverage tone index } \\
+ \text { Economic recession }\end{array}$ & 3.42 & 0.96 & 2.90 & 0.93 & -0.65 & -0.38 & 0.350 .2 & & 0.49 & 0.59 & 0.99 & 0.82 \\
\hline
\end{tabular}

(1) coefficient; ${ }^{*} \mathrm{p}<.1,{ }^{* *} \mathrm{p}<.05,{ }^{* * *} \mathrm{p}<.01$

This study examined how economic situations and media reports affected the plant and equipment prospects of firms. In the BSI analysis for firm plant and equipment investment prospects (see Table 1), future economic situations were found to affect prospects for both small and large firms, when tone of media coverage of the economy was controlled for (small firms: $t=5.57$, large firms: $\mathrm{t}=5.48$ ).

This shows that large firms are more likely to adopt a more positive attitude towards increases in plant and equipment investment than small ones when economic conditions are expected to improve in the future. However, tone of media coverage did not affect firm decisions on plant and equipment investment when relevant variables pertaining to future economic situations were controlled for. This suggests that firm decisions on plant and equipment investment are based on perceived prospects of economic conditions, rather than on media reports. Even when business conditions were poor, media reports on the economy did not affect firm decisions on plant and equipment investment.

Next, the impact of economic news on employer sentiments by firm size was examined. First, analysis focused on whether future economic conditions and tone of media coverage affected employment decision prospects from the perspective of firm size. The results showed that neither leading composite indices nor media coverage provided useful evaluation indicators in determining firm employment policies. That is to say, no firm was found to be greatly affected by predictions or media coverage regarding future economic conditions when forecasting the employment market. Additional examination focused on whether current economic conditions varied their effects on employment prospects for different firm sizes. 
As Table 1 shows, the coincident composite indices representing current economic conditions were not found -1.97). This suggests that small firms view the employment market as generally negative or positive when current economic conditions are good or bad; as shown in Figure 1, the human resources BSI moves in a negative direction, as opposed to the index for actual economic conditions. This appears to stem from a general decrease in the human resources BSI during times of economic boom and a general increase during times of recession. This phenomenon appears plausible in light of characteristics of the employment market, where quality workers tend to flock to larger firms when economic conditions improve, while small firms face a shortage of work.

Table 4 shows the short and long-run relationship between CBS and the macroeconomic variables and dummy variables. Based on the results, in the long-run, LGDPt and LMS2t have positive and significant influence to greatly influence the employment prospects of large firms $(t=-1.15)$, but effects were found for small ones $(t=$ on the LCBSt. Meanwhile, the short-run outcomes are shown; the results indicate that the $\triangle$ LGDPt and $\triangle \mathrm{LMS} 2 \mathrm{t}$ have a positive and significant impact on the $\Delta$ LCBSt. However, the global events' variables (dummy variables) analysis showed that, the Global Financial Crisis (D1) reported a negative impact on the $\triangle \mathrm{LCBSt}$ at high significance level. Meanwhile, the Arab Spring (D2) has a positive and insignificant relationship with $\triangle$ LCBSt. The results indicate that, the error correction term's result for the $\triangle$ LCBSt model is a negative coefficient sign with high statistical significant level. Furthermore, its magnitude which is at -0.5413 indicates a good response and a reasonably high speed of adjustment of the dependent variable to the error correction term. The result implies that the $\triangle$ LCBSt model requires around 1.84 year for adjusting back to the long-run equilibrium.

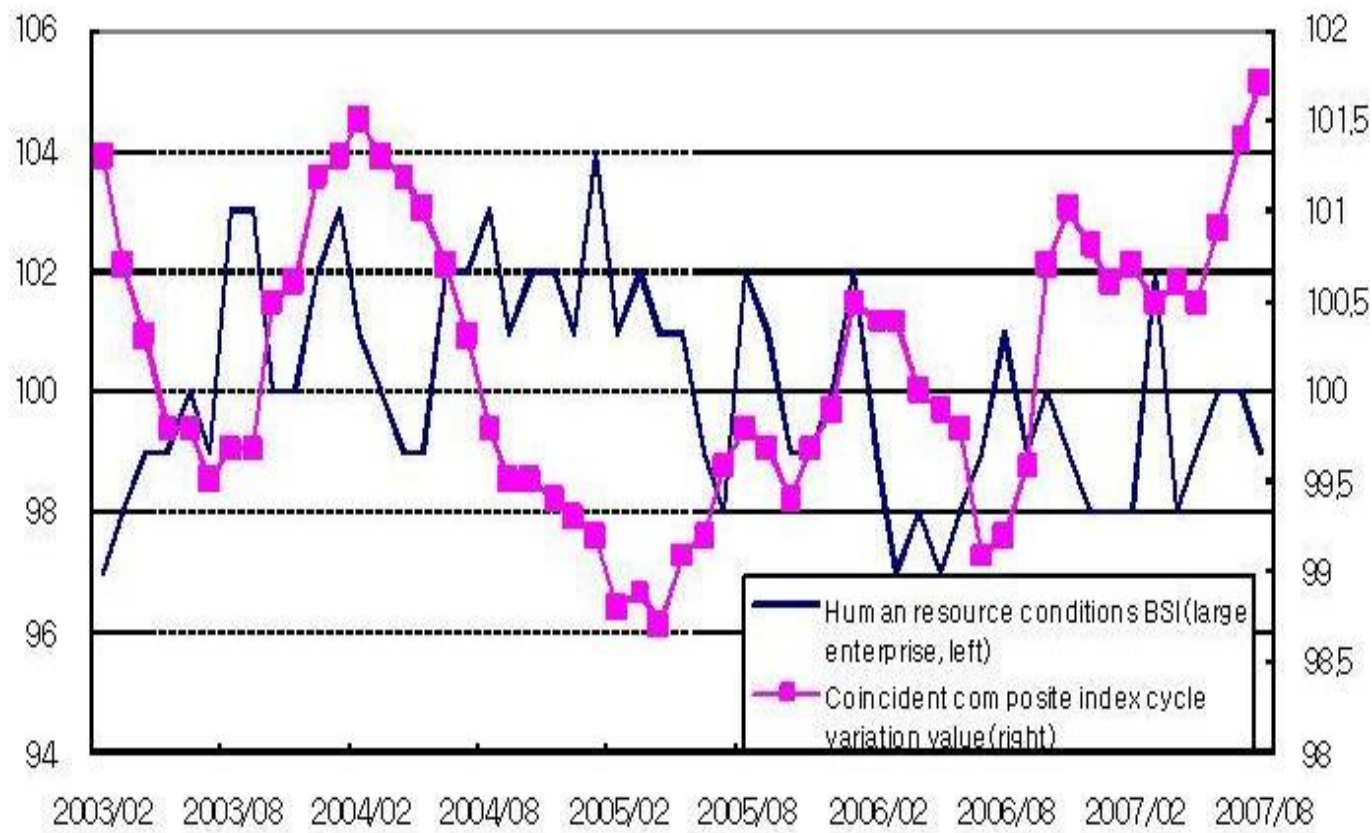

FIGURE 1. Human resources BSI and business conditions

BSI values are separated into three types: business prospects, representing overall economic conditions; plant and equipment investment prospects, relating to facilities investment plans; and human market prospects, relating to supply and demand of human resources. Each BSI figure must be examined in terms of firm size, from which factors such as business prospects, plant and equipment investment prospects, fund circumstances, and employment circumstances can be evaluated or predicted. As seen in Figure 2, BSIs differed in level but showed generally similar trends. This indicates that comprehensive business sentiments at small and large firms move in a similar direction despite differences among individual firms. Thus, it can be concluded that business prospect sentiments follow a very similar 
direction, regardless of firm size. Hence, business sentiments by firm size are statistically composed of stationary time series. At the same time, it is interesting to note that business sentiments vary in level by firm size. As Figure 2 shows, large firms move in a consistently more positive direction $(\mathrm{M}=88.93, \mathrm{SD}=6.29)$ than small ones $(\mathrm{M}=77.71, \mathrm{SD}=5.83)$. Overall, the two time series show a high correlation $(r=.82)$, but large companies have more positive business sentiments and less variable business prospects than small ones. Also, large companies had BSIs of more than 100 at four points during the analysis period, whereas small companies did not have a BSI score of more than 100 at any point. This suggests that small and large companies understand and evaluate identical economic conditions in different ways.

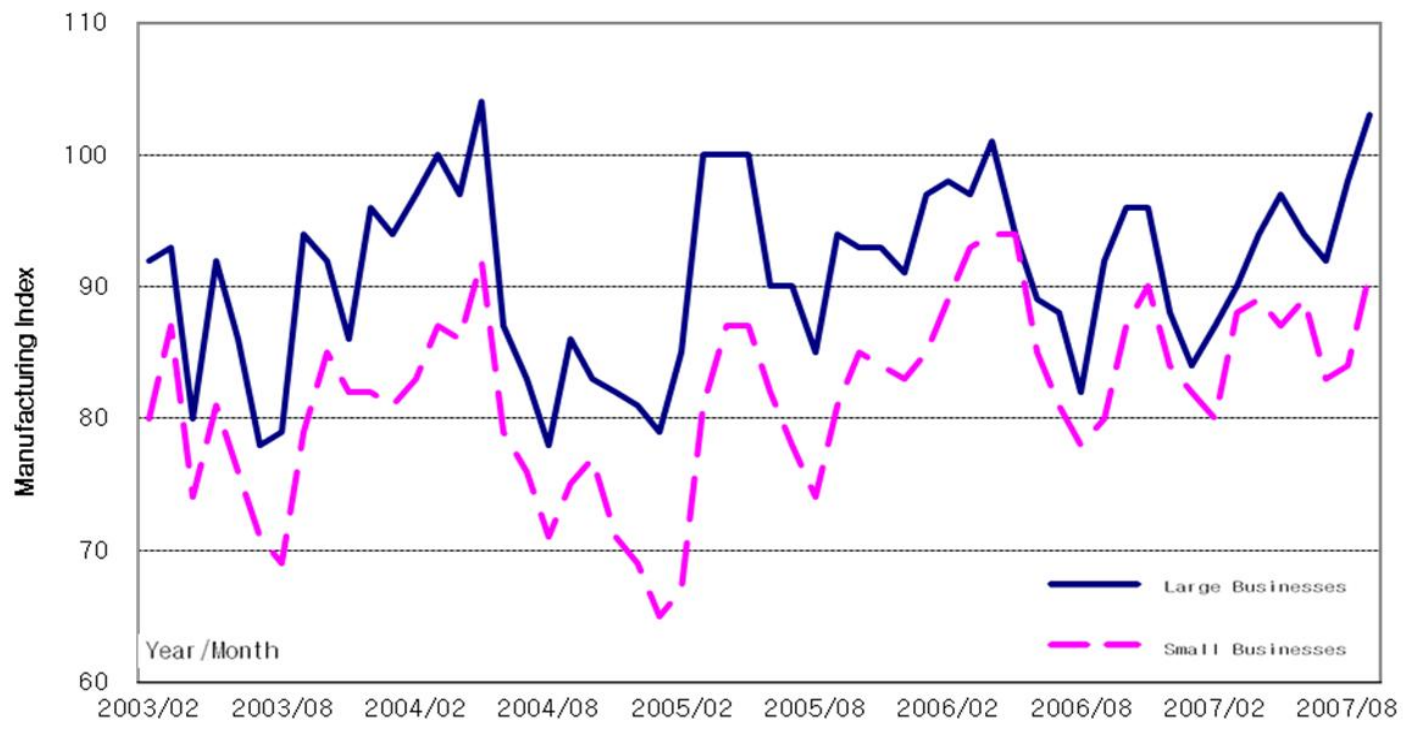

FIGURE 2. BSI trends in firm sizes

\section{RQ3}

This study involved a detailed analysis of the effects of firm-specific BSIs on a firm's direct economic activities, such as production, plant and equipment investment, and on its employment conditions for the period from the first quarter of 1999 to the fourth quarter of 2007. In terms of the relationship between firm-specific BSI values and GDP(gross domestic product) that increases as firm production activities, the findings showed significant effects on GDP rate increase from both small and large firms, even when rates of employee increase or decrease were controlled for (small firms: $t=3.17$, large firms: $t=$ 2.66), as seen in Table 2. However, no difference in influence was observed between small and large firms.

In terms of correlation between business sentiments and GDP, the increased or decreased rates of employment were controlled for because number of employees was strongly associated with firm production activities. Also, when firm business sentiments were controlled for, the increase or decrease in employment rate affected GDP rates for both small $(t=2.42)$ and large $(t=2.22)$ firms. This suggests that an increase in the number of employees functions to promote firm production activities, thereby exerting a positive influence on GDP increase. The next examination focused on whether plant and equipment investment BSI data affected firm decisions on such investment as an element of GDP. Increased firm productivity led to a rise in firm plant and equipment investment, while plant and equipment investment BSI did not affect firm decisions on such investment, regardless of firm size. As detailed in Table 3, plant and equipment investment increased or decreased for both large and small firms ( $t=6.00$ and $t=5.81$, respectively) if such investment increased or decreased from a previous month when firm plant and equipment investment sentiments were controlled for. Additionally, this study examined whether firm human resources BSI data affected business hiring practices. As seen in Table 2, the results showed no effect from BSI on employment levels and no significant difference between firm sizes. In terms of human resources BSI data, results were statistically significant for firms $(\mathrm{t}=3.14)$, but this cannot be viewed as significant because the sign was positive.

An increase or decrease in GDP rates significantly affected increase or decrease in the rate of employment for 
both large $(\mathrm{t}=6.78)$ and small $(\mathrm{t}=8.04)$ firms. Correlations between GDP and human market circumstances were found to be very close. As with plant and equipment investment, employment conditions for a given month were significantly affected by the increase in the number of employees during the previous month for both large and small firms $(t=6.87$ and $t=9.97$, respectively).

TABLE 2. Regression values for relationship between firm-specific BSI sand economic activities (1q99 to 4q07)

\section{Production Activities (GDP Increases)}

\section{Variables}

Model I Model II

Business conditions

BSI

$\begin{array}{ll}\text { (Large } & 0.07\left(2.66^{* *}\right) \\ \text { firm) } & \text { (1) }\end{array}$

(Small

firm)

Increase

rate of

employees

$0.56\left(2.22^{* *}\right)$

Adjusted

$R^{2}$

Variables

GDP

increase

rate

Plant and equipment investment

BSI

Plant and
Equipment
Investment (GDP
Increase Rate)

Model I Model II

$3.78(7.3$ $1 * * *)$

$4.07(8.1$
$\left.4^{* * *}\right)$

(1)

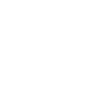

$\begin{array}{lll}\text { Variables } & & \\ \text { GDP } & \text { Model I } & \text { Model II } \\ \text { increase } & 0.33\left(6.78^{*}\right. & 0.35\left(8.04^{* * *}\right) \\ \text { rate } & * *) & \\ \begin{array}{l}\text { Human } \\ \text { resources }\end{array} & & \\ \text { BSI } & & \\ & & \\ (\text { Large } & 0.09(1.67) & \\ \text { firm) } & & 0.09(3.14) \\ (\text { Small } & & \\ \text { firm) } & & \\ \text { Increase } & & \\ \text { rate of } & 0.61\left(6.87^{*}\right. & 0.59\left(9.97^{* * *}\right) \\ \text { employees } & * *) & \\ (-1) & & \\ \text { Adjusted } & 0.85 & 0.87 \\ R^{2} & & \end{array}$

\section{Human Resources \\ (Increase Rates of Employees)}

coefficient(t value); ${ }^{* *} \mathrm{p}<.05,{ }^{* * *} \mathrm{p}<.01$

\section{CONCLUSION AND DISCUSSION}

This study investigated the limited effect of news coverage on business sentiments at a collective level, asymmetrical responses between small and large firms, the nonmediated experience effects of economic conditions on business sentiments, and the Katonian hypothesis of business sentiments on actual economic conditions. The focus of the research was on integrated business communication effects on both business sentiments, and their size, elements that are often discussed as important factors in economics and business management but overlooked in the field of communication. A number of implications can be drawn from the results. First, the effects of economic news were not apparent at an organizational level, whereas the effects of economic news were obvious for individuals. Because firms are capable of collecting information and judging economic conditions, they are less influenced by the media than individuals. Previous studies have shown that mass media are mostly influential in areas that are not accessible to individual experience. However, business organizations that excel in information processing remain relatively unaffected by media. Business organizations can evaluate and interpret economic situations and industries proactively without reliance on media, whereas individuals are limited in their information processing capabilities. While it is true that economic news affect an individual's recognition and evaluation of economic situations, this does not mean that it exerts equal influence on business organizations, which are capable of reinterpreting information holistically at a collective level.

Impact of corporate sentiment on economic downturn was not statically significant. Previous studies interpreted economic news as having a greater influence on people's economic sentiments under recession conditions, but current findings do not support that hypothesis, suggesting that further studies are needed. The current body of evidence, however, suggests that firms may be less affected by news reporting than individuals because firms perceive market circumstances before the reports are released. For example, institutional investors invest in the stock market by evaluating and predicting market 
conditions before media reports are issued. Organizations are more capable of reducing uncertainty in evaluating and predicting economic realities than individuals. In other words, the effects of media on the organization are limited by the latter's independent information processing, interpretation, and decision-making processes. It is also interesting to note that economic communication effects differed for firms of different sizes. Small firms were more vulnerable to economic fluctuations than large firms, even though business sentiments consistently moved in similar patterns under identical economic conditions. This tendency indicates that small firms exhibit a psychological asymmetry relative to large firms, responding more keenly to economic conditions because of their limited resources to overcome these challenges. Economic conditions were found to influence firm business sentiments, plant and equipment investment sentiments, and employer sentiments. Local firms showed non-mediated experience effects, understanding and predicting economic realities through direct experience and evaluation. Generally, business manager sentiments regarding the economy were not influenced by news coverage, but by the firm's financial conditions. In particular, it is interesting to note that firm psychological effects differed in terms of the time frame in which economic situations were evaluated: the present economy influenced small firms alone, while the future economy influenced both small and large firms. Domains within a company's experiences exhibited psychological effects only for small firms, while domains beyond a company's experiences exhibited broad psychological effects regardless of firm size. Small firms are usually affected by current economic conditions, while large ones are rarely affected by current economic circumstances because they excel at collecting and interpreting information. In particular, this paper confirmed that small firms exhibited greater sensitivity to current economic situations than large firms. This is reasonable in terms of the unmediated direct experience model (Blood \& Phillips, 1995), which holds that an obtrusive problem has few media effects. Unlike large firms, small firms show that better the economic conditions, greater the possibilities in developing fear in increasing human resources. This trend implies that when the economy improves, more people working for small firms leave their workplaces for larger firms. The implication of this is that non-mediated experience effects can differ by group size.

In addition, observational data on the connection between firm sentiments and firm economic activities are important in terms of a nation's economic prospects. The GDP sector alone showed effects from firm sentiments on actual production activities, including GDP, plant and equipment investment, and employment. In terms of local consumption, the self-fulfilling hypothesis was not supported for the economy as a whole. Indeed, the data fully supported the conclusion that firm sentiments determined actual economic conditions, but this phenomenon was observed only partially in South Korea, suggesting that this point may require further study. Another focus of this research was on whether size effects existed for domestic firms. As business sentiments were variables in GDP increase, no size-related differences were found among firms. However, this fact alone does not prove that there is no effect on Korean firms from size. As mentioned previously, size effects were especially important for small businesses, which are more dependent on a nation's economic conditions for efficient functioning. This is consistent with the existing literature indicating that a firm is more likely to be affected by external shocks the smaller it is.

Taken together, the findings of this study have theoretical value in a number of respects. First, local firms were found to base their understanding of business realities on direct experiences or social communication rather than on media coverage of the economy. Second, local firms exhibited partial size effects, with large firms evaluating economic conditions more positively and responding to them less keenly than small ones. Third, firm size effects did not occur in predictable economic spheres, but in unpredictable ones. Fourth, local firm concerns did not broadly support the self-fulfilling hypothesis or Katona's (1964) hypothesis that firm business sentiments affect actual economic conditions. Finally, whereas most media studies on businesses have focused on individuals, this research contributed to broadening the scope of media effect studies to the organization level and their quantitative effects.

The findings also hold a number of practical implications. At least for the data in this study, actual economic indicators were found to be a better means than the news for economic actors to predict corporate trends. News reports exhibited only a limited effect on firm psychology, whereas the impact of economic indicators was great. It was also interesting to observe that large firms had more substantial power to control continued economic downturns than smaller firms. This suggests that governments would be advised to pay closer attention to small and medium firms than large ones when local 
economic conditions worsen. Also, governments formulating economic policies should extend more consideration to the actual state of the economy than to public perceptions triggered by news reporting. They may also engage in preemptive management to protect small firms. Both governments and companies should closely monitor firm psychology: the government is advised to consult it in formulating future policies for corporate productivity, plant and facility investment, and the job market, while corporations may find it strategically effective to take the data in account when establishing plant and facility investment and employment plans.

\section{LIMITATIONS AND FUTURE RESEARCH}

While the data yielded important findings, some limitations should be noted. One issue concerns data inco- nsistency: BSI data were analyzed to determine differences in potential effects when relying on firm sizes, but actual firm indices such as GDP, number of employees, and plant and equipment investment were used without classification, as no data set existed for these factors with regard to firm size. In addition, one of the noteworthy findings of the study was that economic news did not have a great effect on business organizations, as opposed to individual consumers. This suggests a need to expand current studies on media effects from the individual level to the organizational level. In particular, the fact that small businesses responded more keenly to external environmental factors than large businesses suggests that business organization size should be taken into careful consideration when researching economic communication effects.

\section{REFERENCES}

Avraham, S. 1993. Marketing strategies during recession: A comparison of small and large firms. Journal of Small Business Management, 31(3), 62-72.

Alwathainani, A.M. 2010. Does bad economic news play a greater role in shaping investors' expectations than good news? Global Economy and Finance Journal, 3(2): 27-43. DOI: 10.2139/ssrn.1626274

Banz, R. 1981. The relationship between return and market value of common stocks. Journal of Financial Economics, 9(1): 3-18. DOI: 10.1016/0304-405X(81)90018-0

Beck, T., Demirguc-Kunt, A., \& Maksimovic, V. 2005. Financial and legal constraints to growth: Does firm size matter? Journal of Finance, 60(1): 137-177. DOI: 10.1111/j.1540-6261.2005.00727.x

Behr, R., \& Iyengar, S. 1985. Television news, real-world cues, and changes in the public agenda. Public Opinion Quarterly, 49(1): 38-57. DOI: 10.1086/268900

Blood, D., \& Phillips, P.C.B. 1995. Recession headlines news, the state of the economy and presidential popularity: A time series analysis, 1989-1993. International Journal of Public Opinion Research, 7(1): 2-22. D0I: 10.1093/ijpor/7.1.2

Boomgaarden, H.G., Van Spanje, J., Vliegenthart, R., \& de Vreese, C. 2011. Covering the crisis: Media coverage of the economic crisis and citizens' economic expectations. Acta Political, 46(1): 353-379. DOI: 10.1057/ap.2011.18

Bovi, M. 2009. Economic versus psychological forecasting: Evidence from consumer confidence surveys. Journal of Economic Psychology, 30(3): 563-574. DOI: 10.1016/j.joep.2009.04.001

Choo, C.W. 1996. The knowing organization: How organizations use information to construct meaning, create knowledge and make decisions. International Journal of Information Management, 16(5): 329-340. DOI: 10.1016/02684012(96)00020-5

Curtin, R.T. 1982. Indicators of consumer behavior: The University of Michigan surveys of consumers. Public Opinion Quarterly, 46(3): 340-352. DOI: 10.1086/268731

Daft, R.L., \& Lengel, R.H. 1986. Organizational information requirements, media richness and structural design. Management Science, 32(5): 554-571. DOI: $10.1287 / \mathrm{mnsc} .32 .5 .554$

Daft, R.L., \& Weick, K.E. 1984. Toward a model of organizations as interpretive systems. Academy of Management Review, 9(2): 284-295. DOI: 10.5465/AMR.1984.4277657

De Boef, S., \& Kellstedt, P.M. 2004. The political (and economic) origins of consumer confidence. American Journal of Political Science, 48(4): 633-649. D0I: 10.2307/1519924

Elfakhani, S., \& Zaher, T. 1998. Differential information hypothesis, firm neglect and the small firm size effect. Journal of Financial and Strategic Decisions, 11(2): 29-30. 
Eshbaugh-Soha, M., \& Peake, J.S. 2005. Presidents and the economic agenda. Political Research Quarterly, 48(1): 127138. DOI: $10.2307 / 3595602$

Fuhrer, J.C. 1988. On the information content of consumer survey expectations. Review of Economics and Statistics, 70(1): 140-144. DOI: $10.2307 / 1928161$

Goidel, R.K., \& Langley, R.E. 1995. Media coverage of the economy and aggregate economic evaluation: Uncovering evidence of indirect media effects. Political Research Quarterly, 48(2): 313-328. D0I: 106591299504800205

Haller, H.B., \& Norpoth, H. 1997. Reality bites: News exposure and economic opinion. Public Opinion Quarterly, 61(4): 555-575. DOI: $10.1086 / 297817$

He, W., Mian, G.M., \& Sankaraguruswamy, S. 2007. Market sentiment, investor size and reaction to firm-specific news. Unpublished paper, NUS Business School, National University of Singapore, Singapore.

Headrick, B., \& Lanoue, D.J. 1991. Attention, asymmetry, and government popularity in Britain. Western Political Research Quarterly, 44(1): 67-86. D0I: 10.2307/448747

Ji, S. 2011. The psychology of small and medium investors under different market environment. Paper presented at the International Conference on Business Computing and Global Informatization (pp. 569-572), Shanghai, China, 2931 July. DOI: $10.1109 /$ bcgin.2011.151

Katona, G. 1964. The mass consumption society. New York, US: McGraw-Hill.

Kim, M.K., \& Burnie, D.A. 2002. The firm size effect and the economic cycle. Journal of Financial Research, 25(1): 111124. DOI: $10.1111 / 1475-6803.00007$

Lewis, A. 2008. Psychology and economic behavior. Cambridge, UK: Cambridge University Press. DOI: $10.1089 / \mathrm{cpb} .2007 .0137$

Linden, F. 1982. The consumer as forecaster. Public Opinion Quarterly, 46(3): 353-360. D0I: 10.1086/268732

Matsusaka, J.G., \& Sbornone, A.M. 1992. Consumer confidence and economic fluctuations. Unpublished mimeograph, University of Chicago, US.

Mutz, D.C. 1998. Impersonal influence: How perceptions of mass collectives affect political attitude. New York, US: Cambridge University Press. DOI: 10.1017/CB09781139175074

Narjoko, D., \& Hill, H. 2007. Winners and losers during a deep economic crisis: Firm-level evidence from Indonesian manufacturing. Asian Economic Journal, 21(4): 343-368. DOI: 10.1111/j.1467-8381.2007.00261.x

Ranyard, R., Missier, F.D., Bonini, N., Duxbury, D., \& Summers, B. 2008. Perceptions and expectations of price changes and inflation: A review and conceptual framework. Journal of Economic Psychology, 29(4): 378-400. D0I: 10.1016/j.joep.2008.07.001

Reinganum, M. 1981. Misspecification of capital asset pricing: Empirical anomalies based on earning yields and market. Journal of Financial Economics, 9(1): 19-46. DOI: 10.1016/0304-405X(81)90019-2

Roland-Levy, C., \& Kirchler, E. 2009. Psychology in the economic world. Applied Psychology: An International Review, 58(3): 363-369. DOI: 10.1111/j.1464-0597.2009.00395.x

Scheufele, D., \& Tewksbury, D. 2007. Framing, agenda-setting, and priming: The evolution of three media effects models. Journal of Communication, 57(1): 9-20. DOI: 10.1111/j.1460-2466.2006.00326.x

Schneider, S.C. 1997. Interpretation in organizations: Sense making and strategy. European Journal of Work and Organizational Psychology, 6(1): 93-102. DOI: 10.1080/135943297399321

Shirvani, H., \& Wilbratte, B. 2008. Stock price, consumer sentiment, and economic activity: Some robust bilateral causality tests for the US and the UK. International Business \& Economic Research Journal, 7(1): 29-34.

Shrader, C.B., Mulford, C.L., \& Blackburn, V.L. 1989. Strategic and operational planning, uncertainty, and performance in small firms. Journal of Small Business Management 27(4): 45-60.

Sims, C. 2003. Implications of rational inattention. Journal of Monetary Economics, 50(3): 665-656. D0I: 10.1016/S0304-3932(03)00029-1

Sill, K. 2009. News about the future and economic fluctuations. Business Review, Q4: 22-33.

Soroka, S.N. 2006. Good news and bad news: Asymmetric response to economic information. Journal of Politics, 68(2): 372-385. DOI: 10.1111/j.1468-2508.2006.00413.x

Turner, K.L., \& Makhija, M.V. 2012. The role of individuals in the information processing respective. Strategic Management Journal, 33(2): 661-680. D0I: 10.1002/smj.1970

ISSN: 2414-309X

DOI: $10.20474 / j a b s-2.1 .4$ 
Uhl, M.W. 2011. Explaining U.S. consumer behavior with news sentiment. ACM Transactions on Management Information Systems, 2(2): 1-18. DOI: 10.1145/1985347.1985350

Wu, H.D., McCracken, M.W., \& Saito, S. 2004. Economic communication in the 'lost decade'. Gazette. International Journal for Communication Studies, 66(2): 133-149. DOI: 10.1177/0016549204041474

Wu, H.D., Stevenson, R.L., Chen. H.C., \& Guner, Z.N. 2002. The conditioned impact of recession news: A time-series analysis of economic communication in the United States, 1987-1996. International Journal of Public Opinion Research, 14(1): 19-36. DOI: 10.1093/ijpor/14.1.19

— This article does not have any appendix. - 